\title{
Laparoendoscopic Single Site Total Hysterectomy: Single Institution Initial Experience
}

\author{
Laparoendoskopik Tek Giriş Total Histerektomi: \\ Tek Merkez Başlangıç Deneyimi
}

\author{
Mehmet Ali VARDAR, ${ }^{a}$ \\ Ahmet Barış GÜZEL, ${ }^{a}$ \\ Ümran KÜÇÜKGÖZ GÜLEÇ, ${ }^{a}$ \\ Mete SUCU, \\ Ghanim KHATIBa \\ aDepartment of Obstetrics and \\ Gynecology, \\ Çukurova University Faculty of Medicine, \\ Adana
}

Geliş Tarihi/Received: 10.01.2017

Kabul Tarihi/Accepted: 23.05.2017

Yazışma Adresi/Correspondence: Ümran KÜÇÜKGÖZ GÜLEÇ

Cukurova University

Faculty of Medicine,

Department of Obstetrics and

Gynecology, Adana,

TURKEY/TÜRKIYE

ukucukgoz@yahoo.com

\begin{abstract}
Objective: To compare the peri- and post-operative outcomes between the laparoendoscopic transumblical single-site total hysterectomy (LESS-TH) and conventional three-port total laparoscopic hysterectomy (TLH). Material and Methods: A single institution retrospective review of patients operated on with LESS-TH $(n=24)$ and TLH $(n=47)$ for benign uterine pathology or endometrial cancer with low-risk factors from March 2013 to March 2014. Patients underwent LESSTH surgery through a single $2-3 \mathrm{~cm}$ transumbilical incision with a multi-channel SILS TM port (Covidien $^{\circledast}$, Mansfield, MA, USA). Patient demographics and peri-operative and post-operative variables were analyzed and compared between the groups. Results: There was one conversion to conventional laparoscopy and one conversion to laparotomy in the LESS-TH group, and no cases converted to laparotomy in the LTH group. Demographic characteristics such as age, body mass index (BMI), and indications were similar between the groups ( $\mathrm{p}=0.497,0.07,0.594$, respectively). Operation time was significantly longer in the LESS-TH group than in the TLH group $(\mathrm{p}=0.01)$. The other peri- and post-operative variables such as uterus length and width, estimated blood loss, post-operative $\mathrm{Hb}$ level drop, post-operative hospitalization time and analgesic management were found to be similar between the two groups. There were no major complications in either of the groups. Conclusion: With the exception of operative time, the surgical outcomes of the LESS-TH group were comparable to those of the conventional multiport TLH group.
\end{abstract}

Keywords: Endometrial neoplasms; laparoscopy; hysterectomy

ÖZET Amaç: Konvansiyonel 3 portla yapılan total laparoskopik histerektomi (TLH) ile Laparoendoskopik transumbilikal tek giriş total histerektominin (LESS-TH) peri ve postoperatif sonuçlarının karşılaştırılması. Gereç ve Yöntemler: Tek merkezde Mart 2013 ve Mart 2014 tarihleri arasında benign uterin nedenler ve düşük risk faktörlü endometrial kanser vakalarında yapılan LESS-TH ( $\mathrm{n}=24)$ ile TLH $(\mathrm{n}=47)$ olguları retrospektif olarak değerlendirilmiştir. LESS-TH, tek bir 2-3 cm'lik transumbilikal insizyona uygulanan multi-channel SILS TM port (Covidien ${ }^{\circledR}$, Mansfield, MA, USA) ile yapılmıştır. Hastaların demografik özellikleri, peri ve postoperatif özellikleri her iki grupta değerlendirilmiş ve karşılaştırılmıştır. Bulgular: LESS-TH grubundan bir hastada konvansiyonel laparoskopiye, bir vakada ise laparotomiye dönülmüsstür. Yaş, beden kitle indeksi (BKİ) gibi demografik özellikler ve endikasyonlar her iki grupta da benzerdir ( $\mathrm{p}=0,497,0,07,0,594$, sırasıyla). LESS-TH grubunda operasyon süresi TLH grubuna göre belirgin yüksekti $(\mathrm{p}=0,01)$. Uterusun eni, boyu, tahmini kan kaybı, postoperatif $\mathrm{Hb}$ seviyesinde düşme, postoperatif hastanede kalış süresi, analjezik tedavisi gibi diğer peri ve postoperatif özellikler her iki grup arasında benzerdi. Her iki grupta da major komplikasyonumuz olmadı. Sonuç: Operasyon süresi dışında LESS-TH'in cerrahi sonuçları, konvansiyonel multiport TLH' ye benzerdir.

Anahtar Kelimeler: Endometrial neoplaziler; laparoskopi; histerektomi

single-port approach has been used for hysterectomy and bilateral salpingo-oophorectomy by Pelosi and Pelosi since 1991, with the -aim of reducing the invasiveness of conventional laparoscopy. ${ }^{1}$ Ho- 
wever, this approach initially did not gain popularity because of the technical limits of the laparoendoscopic transumblical single-site (LESS) procedure. Recently, innovations in the technology such as multi-channel single-port, articulating instruments, and flexible endoscopes have allowed laparoscopic surgeons to perform increasingly complex gynecological and gynecologic-oncologic operations. ${ }^{2-7}$

A recent systematic review by Mencaglia et al. identified 65 studies (17 case reports, 32 cases studies, 13 retrospective comparative studies and three randomized clinical trials) and reported that LESS is safe and feasible for most benign gynecologic surgeries. ${ }^{8}$ A randomized clinical trial that evaluated LESS compared to conventional laparoscopic-assisted vaginal hysterectomy reported significant decreases in post-operative pain and analgesic use in the LESS-assisted vaginal hysterectomy group. ${ }^{9}$ A comparative cross-sectional study on cosmetic outcomes after LESS and conventional laparoscopic gynecologic surgery reported that LESS offers better cosmetic and overall patient satisfaction. ${ }^{10} \mathrm{At}$ the beginning, LESS is generally used with vaginal hysterectomy as an assisted procedure. ${ }^{9-12}$ There are fewer studies in the literature on LESS -TH than on LESS-assisted vaginal hysterectomy. ${ }^{3,7,13}$

In this study, we present our experience on total hysterectomy with LESS and make a retrospective comparative analysis of the surgical outcomes for LESS-TH and conventional TLH.

\section{MATERIAL AND METHODS}

We evaluated 24 patients who underwent LESS$\mathrm{TH}$ and 47 matched patients who underwent conventional TLH for benign and malignant uterine pathology from March 2013 to March 2014. Patients were informed about the LESS-TH or conventional TLH and the conversion risk of multi-port laparoscopy or laparotomy. Informed consent was obtained from each patient. Patients were selected with following criteria: normal to moderately enlarged uterus (uterine size $<12$ weeks of gestation) with a diagnosis of benign endometrial and uterine pathology, low-risk premalignant and malignant endometrial pathology (endometri- oid histology, FIGO grade 1 or 2, and no evidence of lymph node and/or adnexal and/or cervical involvement on high-resolution transvaginal ultrasonography or computerized tomography), no history of previous vertical incision, and a body mass index $(\mathrm{BMI}) \leq 35$ and ASA score I-II. Patient demographic characteristics (age, BMI, parity, history of previous abdominal surgery and the presence of co-morbidities), operation time (min), estimated blood loss (EBL, ml), intra-operative complications (vascular injuries, bleeding [estimated blood loss $>500 \mathrm{ml}$ ], urinary tract or bladder injury, gastro-intestinal injury), post-operative complications (bleeding, ileus, fever, infections of the port site or vaginal cuff, surgical re-evaluation, bladder dysfunction) post-operative hospitalization time (day), follow-up time (month), and analgesic type (classified as: 1- parenteral non-steroid antiinflammatory drugs (NSAIDS), 2-parenteral opioids, 3- parenteral NSAIDS and opioids) were recorded. Operation time was defined as, the interval between incision start to skin closure. All patients received general anesthesia by the consultant anesthesiologist. In our clinic, we used the clindamycin and gentamycin antibiotherapy for the antibiotic prophylaxis of laparoscopic surgery for all patients. All patients with a diagnosis of endometrial biopsy as, complex atypical hyperplasia and endometrial cancer were evaluated with an intra-operative frozen section. The frozen section time was removed from the operation time. The patients with FIGO grade 1 or grade 2 endometrioid adenocarcinoma and less than $50 \%$ myometrial invasion only had extra-facial hysterectomy and bilateral salpingo-oophorectomy performed.

\section{SURGICAL TECHNIQUES}

All operations were performed by the same two surgeons (M.A.V, A.B.G). We have performed the laparoscopic hysterectomy at our gynecologic-oncology clinic since 2004. After general anesthesia and with the patient in the lithotomy position with both legs supported in stirrups, a 16 G Foley catheter was inserted into the bladder and an orogastric tube was inserted for all patients. The orogastric tubes were removed at the end of the 
operation by an anesthesiologist, and the Foley catheter was removed on postoperative day one. A Clermont Ferrand (Karl-Storz ${ }^{\mathrm{TM}}$, Tuttlingen, Germany) uterine manipulator was placed in the cervical canal to manipulate the uterus at the beginning of the skin incision.

TLH: A $10 \mathrm{~mm}$, vertical intra-umbilical incision was made after the appropriate $\mathrm{CO}_{2}$ pneumoperitoneum by veres needle. A $10 \mathrm{~mm}$ trocar was inserted bluntly through the umbilicus. A rigid $0^{0}$, $10 \mathrm{~mm}$ laparoscope was introduced. Two ancillary $5 \mathrm{~mm}$ trocars were inserted at the McBurney and counter McBurney point through direct visualization with a Trendelenburg tilt. A careful inspection of the entire abdominal cavity was performed as the first surgical step to identify any suspicious peritoneal lesions. Peritoneal washing was not routinely performed. The round ligaments were ligated bilaterally by $5 \mathrm{~mm}$ Ligasure Advance ${ }^{\mathrm{TM}}$ (Covidien ${ }^{\circledR}$, Mansfield, MA, USA) and after identification of the ureters, the infundibulopelvic ligaments were ligated. A bladder flap was developed by using scissors with mono-polar energy and ecarted the cervix. The bilateral uterine arteries were identified and ligated by ligasure. The bilateral sacrouterine and cardinal ligaments were ligated and circumferential colpotomy was performed using the monopolar Lhook. After the specimen was removed through the vagina, the vaginal cuff was closed through the vaginal route using 1.0 absorbable suture material (Vicryl $^{\mathrm{TM}}$, Ethicon, USA) with continuous locking sutures. After the hemostasis, the trocars were removed with direct visualization. The skin was closed subcutaneously by no: 2.0 absorbable suture material (Biosyn ${ }^{\mathrm{TM}}$, Covidien, USA).

LESS-TH: A single $2-3 \mathrm{~cm}$ vertical transumbilical incision was performed by an open technique. The SILS ${ }^{\mathrm{TM}}$ port (Covidien ${ }^{\circledR}$, Mansfield, MA, USA) was used for all cases in this group (Figure 1). After insertion of the port and insufflation of the abdomen with $\mathrm{CO}_{2}$ gas, a blunt $5 \mathrm{~mm}$ trocar was inserted through the most cephalad channel and $0^{0}, 10 \mathrm{~mm}$ laparoscope was introduced. Two additional $5 \mathrm{~mm}$ trocars were inserted for using the flexible laparoscopic devices through the other two

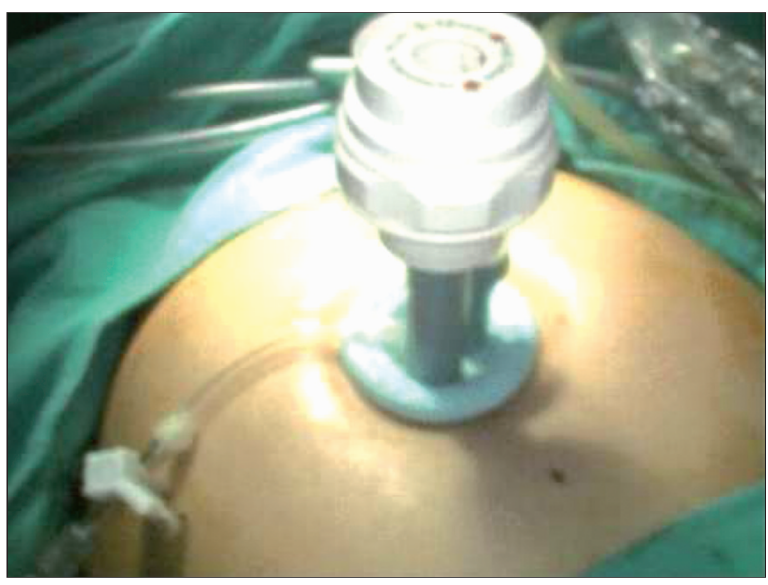

FIGURE 1: SILS port application.

other channels. The procedures of the hysterectomy were same the as the TLH. We used the two flexible devices at the same time for LESS-TH in the first five cases, but one flexible device and one rigid device were used for the other LESS-TH cases. The flexible device was a grasping forceps and the rigid devices were a ligasure and scissors in all of the cases. All of the procedures were performed using $\mathrm{CO}_{2}$ pneumo-peritoneum with a maximum of $15 \mathrm{mmHg}$ intra-abdominal pressure. The vaginal cuff was repaired as described above. After completing the procedure, the SILS port was removed and the umbilical fascia was sutured by no: 1.0 absorbable suture material using the retractors. The skin was closed subcutaneously using no: $2.0 \mathrm{ab}-$ sorbable suture materials (Biosyn ${ }^{\mathrm{TM}}$, Covidien, USA).

Statistical analysis was performed with SPSS version 20. The Student's t test and the MannWhitney $U$ test were used for the parametric and non-parametric variables, respectively. Comparison of the categorical variables between the groups was performed using the Chi-Square test. A P value of less than 0.05 was regarded as significant.

\section{RESULTS}

A total of 71 patients were included in this study. Two patients in the LESS-TH group were removed from this analysis because one of them was converted to multi-port laparoscopy with technical difficulty, and the other was converted to laparo- 
tomy because of the necessity of the surgical-staging procedures and frozen section evaluation results. The results of the 69 patients were included in the analysis; 22 patients in the LESS-TH group and 47 patients in the conventional LTH group.

Age, BMI, parity, previous abdominal surgery, and the presence of co-morbidities such as hypertension or diabetes mellitus were not different between the groups $(\mathrm{p}=0.497,0.07,0.579,0.431$, respectively). The indications for hysterectomy were not significantly different between the groups $(\mathrm{p}=0.594)$. The demographic characteristics and operation indications are presented in Table 1 . The intra-operative and post-operative variables and the comparison of these two variables are presented in Table 2. The only significant difference was in the median operative time between the groups. The LESS-TH group had a significantly longer operation time than the TLH group ( $\mathrm{p}=0.01)$. One of the patients received a blood transfusion (two erythrocyte suspensions) intra-operatively because the pre-operative $\mathrm{Hb}$ value was $7.4 \mathrm{~g} / \mathrm{dl}$. Two patients in both groups had pelvic adhesions, but this factor did not change the management of the operation.

\begin{tabular}{|c|c|c|c|}
\hline \multicolumn{4}{|c|}{$\begin{array}{l}\text { TABLE 1: Patients demographics and } \\
\text { indications of hysterectomy. }\end{array}$} \\
\hline & $\begin{array}{l}\text { LESS-TH } \\
(\mathrm{n}=22) \\
\text { Mean } \pm S D \\
\text { Median } \\
\text { Min-max }\end{array}$ & $\begin{array}{l}\text { TLH } \\
(\mathrm{n}=47) \\
\text { Mean } \pm S D \\
\text { Median } \\
\text { Min-max }\end{array}$ & $\mathrm{p}$ \\
\hline Age (year) & $\begin{array}{l}53.7 \pm 7.8 \\
52 \\
43-78\end{array}$ & $\begin{array}{l}52.3 \pm 8.2 \\
51 \\
40-78\end{array}$ & 0.497 \\
\hline BMl & $\begin{array}{l}28.9 \pm 3.7 \\
29 \\
20-35\end{array}$ & $\begin{array}{l}30.0 \pm 3.5 \\
30 \\
21-35\end{array}$ & 0.07 \\
\hline Nulliparity & 2 & 1 & 0.09 \\
\hline Previous abdominal surgery & 7 & 12 & 0.579 \\
\hline Co-morbidity & 7 & 21 & 0.431 \\
\hline Indication & & & \\
\hline Myoma uteri & 4 & 12 & 0.594 \\
\hline Endometrial hyperplasia & 8 & 20 & \\
\hline Prophylactic & 3 & 2 & \\
\hline Endometrial carcinoma & 7 & 13 & \\
\hline
\end{tabular}

BMI: Body-mass index.
There were no intra-operative complications for the included patients, but two post-operative complications occurred: one was vaginal cuff cellulitis, and the other was post-operative febrile morbidity with urinary tract infection. Both of the patients were in the TLH group and were hospitalized and then discharged after healed. None of the patients underwent surgical re-exploration for complications.

\section{DISCUSSION}

LESS-TH was developed with the aim of reducing post-operative pain and providing better cosmetic results. However, this technique has not gained popularity among surgeons for the main reason that it is more difficult than conventional laparoscopy, particularly because of the limited movement of the surgical devices, and the required technological equipment such as a multi-channel single port and articulated instruments. Technological innovation resulted in the increased use of LESS-TH, not only for benign gynecologic surgery but also for endometrial cancer surgery and lymphadenectomy. ${ }^{2,4,6}$ Our results showed no significant differences in terms of estimated blood loss, post-operative $\mathrm{Hb}$ drop and post-operative hospitalization time between the LESS-TH group and the conventional multi-port TLH group, and this finding is consistent with previous study. ${ }^{3}$ However, the operation time was longer in the LESS-TH group. Longer operation times with the LESS-TH procedure were reported in some studies however, there were similar results in some others. ${ }^{13,14}$

LESS-TH in gynecologic oncology was first reported in 2009 as a single-institution retrospective review by Fader and Escobar on 13 gynecologic oncology cases. ${ }^{6}$ Fanfani then reported the LESS-TH surgery results of twenty patients with low-risk endometrial cancer. ${ }^{2}$ Not only extra-facial hysterectomy but also pelvic and para-aortic lymphaden ectomy and also bulky lymphadenectomy were reported in the literature by single port robotic technique. ${ }^{4}$ The authors of these studies concluded that LESS-TH surgery for endometrial carcinoma is feasible when compared with conventional la- 
TABLE 2: Peri- and post-operative outcomes of the patients and comparison of the groups.

\begin{tabular}{|c|c|c|c|}
\hline & $\begin{array}{l}\text { LESS-TH } \\
(\mathrm{n}=22) \\
\text { Mean } \pm S D \\
\text { Median } \\
\text { Min-max }\end{array}$ & $\begin{array}{l}\text { TLH } \\
(n=47) \\
\text { Mean } \pm S D \\
\text { Median } \\
\text { Min-max }\end{array}$ & $p$ \\
\hline BSO & 22 & 44 & 0.226 \\
\hline Pelvic adhesion & 2 & 2 & 0.587 \\
\hline Operation time (min) & $\begin{array}{l}79.3 \pm 35.6 \\
70 \\
30-180\end{array}$ & $\begin{array}{l}58.4 \pm 18.7 \\
60 \\
24-100\end{array}$ & 0.01 \\
\hline EBL (ml) & $\begin{array}{l}94.0 \pm 103 \\
50 \\
20-400\end{array}$ & $\begin{array}{l}54.2 \pm 37.8 \\
50 \\
10-200\end{array}$ & 0.075 \\
\hline Drop in Hb level (g/dl) & $\begin{array}{l}0.96 \pm 0.8 \\
0.85 \\
0-3\end{array}$ & $\begin{array}{l}0.68 \pm 1.2 \\
0.3 \\
0-3\end{array}$ & 0.325 \\
\hline Post-operative & $2.1 \pm 0.8$ & $2.8 \pm 2$ & 0.141 \\
\hline Hospitalization time (day) & $\begin{array}{l}2 \\
1-5\end{array}$ & $\begin{array}{l}2 \\
1-13\end{array}$ & \\
\hline Uterus lenght (cm) & $\begin{array}{l}9.7 \pm 4 \\
8.5 \\
3.5-15\end{array}$ & $\begin{array}{l}10.1 \pm 4.2 \\
9 \\
3-16\end{array}$ & 0.556 \\
\hline Uterus width (cm) & $\begin{array}{l}6.5 \pm 2.3 \\
6 \\
3-12\end{array}$ & $\begin{array}{l}7.2 \pm 3.2 \\
7 \\
3-12\end{array}$ & 0.394 \\
\hline \multicolumn{4}{|l|}{ The management of analgesia } \\
\hline 1-NSAID & 1 & 1 & 0.823 \\
\hline 2-Opioids & 1 & 3 & \\
\hline 3-NSAID+Opioids & 20 & 43 & \\
\hline Post-operative complications & 0 & 2 & 1 \\
\hline Post-operative follow-up & 16 & 36 & 0.708 \\
\hline
\end{tabular}

BSO: Bilateral salpingo-oophorectomy, EBL: Estimated blood loss, NSAID: Nonsteroidal antiinflammatory drugs.

paroscopy and robotic surgery. In these studies, the majority of the patients had low-risk factors. We performed the LESS-TH in seven patients with low-risk endometrial cancer. However, there is still a lack of data on any cost-benefit analysis and more importantly on long-term oncologic results.

In the literature, there are only two randomized controlled trials and some retrospective cohort studies related with the LESS-TH procedure. In one of these studies, LESS-TH was performed in en- dometrial cancer cases..$^{3,7,13,15-18}$ In another study, the same procedure was used for the treatment of benign and malignant uterine pathologies. Jung et al. reported that the mean operation time was 89 min. in the LESS-TH group, and was $80 \mathrm{~min}$. in the four-port TLH group ( $\mathrm{p}=0.175) .{ }^{16}$ They were no differences found between the groups for peri-operative and post-operative outcomes except the total analgesics request. Higher total requests for analgesics were observed in the LESS-TH group in this study. Li et al. reported that operative time was longer in LESS-TH group than multiport TLH group (130 min. versus $112 \mathrm{~min}$.). ${ }^{15}$ The mean operative time was $93.5 \mathrm{~min}$. in another study. ${ }^{3} \mathrm{~A}$ longer operative time (175 $\mathrm{min}$ ) was reported by Fagotti et al. which included the patients with endometrial cancer. ${ }^{18}$ The time was $105 \mathrm{~min}$. in the Fanfani et al. study, which included the patients with benign and malignant uterine pathology. ${ }^{17}$ These results are longer than our mean operative time (79.3 min). This difference was explained by the closure technique of the vaginal cuff. The vaginal cuff was sutured laparoscopically in all of these studies, however we repaired the vaginal cuff vaginally. The authors of the presented studies reported that the most difficult procedure was the vaginal vault suture with the laparoscopic suture techniques. The longer operative time was explained by the technical difficulties, especially the relatively restricted placement of the surgeon's hand within a fairly narrow field, the limited range of motion, the interference of instruments and of course, changes according to indication. We had a learning curve for LESS-TH; therefore, the longer operation times in LESS-TH group were expected. In the first five cases, we used two flexible laparoscopic devices at the same time for both of the 5 $\mathrm{mm}$ trocars. One of these instruments was a grasping forceps or a bipolar forceps and the other was scissors. However, because of the difficulty of using two flexible instruments at the same time, we have changed our operative technique after our fifth case. Moreover, we used one flexible and one rigid device simultaneously for the other LESS-TH cases thereafter. Thus, the time of surgery was shortened 
and the operations have become easier for us. However, this technical detail is only an opinion arising from our experience and is open for discussion. In our experience, this technique may not be recommended yet. A recent meta-analysis on LESS-TH demonstrated that the only difference in operative outcomes of the LESS-TH was longer operative time than multiport TLH. ${ }^{19}$ In this study concluded that LESS-TH for benign hysterectomy is feasible, safe, and equally effective compared to the conventional technique but the clinical benefits have not been clearly demonstrated.

Our study has limitations, as do all retrospective studies. One serious limitation was the susceptibility to bias of the selection of patients for surgery types. However, we attempted to minimize any significant difference between the groups by matching the patients in the TLH group according to age, BMI, indication and the risk factors of the patients with endometrial cancer. Our study has a relatively small number of cases in the LESS-TH group, but this report is our initial LESS-TH experience for hysterectomy.

Our preliminary results showed that LESS-TH is a feasible method for hysterectomy with comparable peri-operative surgical outcomes. LESS-TH requires more time and effort to acquire the necessary skills than conventional multi-port TLH but is feasible and acceptable. In conclusion, the oncologic outcomes of these laparoscopic techniques should be investigated by randomized controlled studies.

\section{Conflict of Interest}

Authors declared no conflict of interest or financial support.

\section{Authorship Contributions}

Concept-Design: Mehmet Ali Vardar, Ahmet Barış Güzel, Ümran Küçükgöz Güleç. Data Collection: Ümran Küçükgöz Güleç; Analysis, Writing: Ümran Küçükgöz Güleç, Mete Sucu, Ghanim Khatib, Supervision, Consultancy: Mehmet Ali Vardar, Ahmet Barış Güzel.

\section{REFERENCES}

1. Pelosi MA, Pelosi MA 3rd. Laparoscopic hysterectomy with bilateral salpingo-oophorectomy using a single umbilical puncture. $\mathrm{N} \mathrm{J}$ Med 1991;88(10): 721-6.

2. Fanfani $F$, Rossitto $C$, Gagliardi ML, Gallotta V, Gueli Alletti S, Scambia G, et al. Total laparoendoscopic single-site (LESS) hysterectomy in low risk endometrial cancer: a pilot study. Surg Endosc 2012;26(1):41-6.

3. Wang T, Chong GO, Park NY, Hong DG, Lee YS. Comparison study of single-port (Octoport ${ }^{\mathrm{TM}}$ ) and four-port total laparoscopic hysterectomy. Eur J Obstet Gynecol Reprod Biol 2012;161(2): 215-8.

4. Gungor M, Takmaz O, Afsar S, Ozbasli E, Gundogan S. Single-port robotic pelvic bulky lymph node resection: a case report. J Minim Invasive Gynecol 2016;23(7):1030-1.

5. Sendag F, Akdemir A, Simsek D, Oztekin MK. Single-port laparoscopy for deep infiltrating endometriosis surgery. J Minim Invasive Gynecol 2015;22(6S):140.

6. Fader AN, Escobar PF. Laparoendoscopic single-site surgery (LESS) in gynecologic oncology: technique and initial report. Gynecol Oncol 2009; 114(2):157-61.
7. Kale A, Terzi H, Yavuz A, Kale E. Single-port access total laparoscopic hysterectomy with Korean-made OCTO Port: Turkish surgeons' initial experience. J Obstet Gynaecol 2016; 36(1):114-8.

8. Mencaglia L, Mereu L, Carri G, Arena I, Khalifa $\mathrm{H}$, Tateo $\mathrm{S}$, et al. Single port entry-are there any advantages? Best Pract Res Clin Obstet Gynaecol 2013;27(3):441-55.

9. Chen YJ, Wang PH, Ocampo EJ, Twu NF, Yen MS, Chao KC. Single-port compared with conventional laparoscopic-assisted vaginal hysterectomy: a randomized controlled trial. Obstet Gynecol 2011;117(4):906-12.

10. Eom JM, Ko JH, Choi JS, Hong JH, Lee JH. A comparative cross-sectional study on cosmetic outcomes after single port or conventional laparoscopic surgery. Eur J Obstet Gynecol Reprod Biol 2013;167(1):104-9.

11. Kim TJ, Lee YY, Cha HH, Kim CJ, Choi $\mathrm{CH}$, Lee JW, et al. Single-port-access laparoscopic-assisted vaginal hysterectomy versus conventional laparoscopic-assisted vaginal hysterectomy: a comparison of perioperative outcomes. Surg Endosc 2010; 24(9):2248-52.
12. Choi YS, Park JN, Oh YS, Sin KS, Choi J, Eun DS. Single-port vs. conventional multi-port access laparoscopyassisted vaginal hysterectomy: comparison ofsurgical outcomes and complications. Eur J Obstet Gynecol Reprod Biol 2013;169(2):366-9.

13. Yim GW, Jung YW, Paek J, Lee SH, Kwon HY, Nam EJ, et al. Transumbilical single-port access versus conventional total laparoscopic hysterectomy: surgical outcomes. Am J Obstet Gynecol 2010;203(1):26.e1-6.

14. Jung YW, Kim YT, Lee DW, Hwang YI, Nam EJ, Kim JH, et al. The feasibility of scarless single-port transumbilical total laparoscopic hysterectomy: initial clinical experience. Surg Endosc 2010;24(7): 1686-92.

15. Li M, Han Y, Feng YC. Single-port laparoscopic hysterectomy versus conventional laparoscopic hysterectomy: a prospective randomized trial. J Int Med Res 2012;40(2):7018

16. Jung YW, Lee M, Yim GW, Lee SH, Paek JH, Kwon HY, et al. A randomized prospective study of single-port and four-port approaches for hysterectomy in terms of postoperative pain. Surg Endosc 2011;25(8):2462-9. 
17. Fanfani F, Fagotti A, Rossitto C, Gagliardi ML, Ercoli A, Gallotta V, et al. Laparoscopic, minilaparoscopic and single-port hysterectomy: perioperative outcomes. Surg Endosc 2012;26(12):3592-6

18. Fagotti A, Boruta DM 2nd, Scambia G, Fan- fani F, Paglia A, Escobar PF. First 100 early endometrial cancer cases treated with laparoendoscopic single-site surgery: a multicentric retrospective study. Am J Obstet Gynecol 2012;206(4):353. e1-6.
19. Sandberg EM, la Chapelle CF, van den Tweel MM, Schoones JW, Jansen FW. Laparoendoscopic single-site surgery versus conventional laparoscopy for hysterectomy: a systematic review and meta-analysis. Arch Gynecol Obstet 2017;295(5):1089-103. 